Suska Journal of Mathematics Education

Vol.2, No. 1, 2016, Hal. 57 - 66

\title{
Implementasi Program Aplikasi Maple untuk Meningkatkan Prestasi dan Motivasi Belajar Mahasiswa pada Perkuliahan Kalkulus Integral
}

\author{
Suhandri \\ Fakultas Tarbiyah dan Keguruan UIN SUSKA RIAU \\ Email: suhandri@uin-suska.ac.id
}

\begin{abstract}
ABSTRAK. Kalkulus merupakan salah satu pelajaran yang sulit bagi mahasiswa, membuat para pengajar berusaha membuat terobosan baru dalam proses mentransfer ilmu di kelas, salah satunya adalah memanfaatkan teknologi komputasi dengan menggunakan software Maple sebagai upaya meningkatkan Prestasi dan motivasi belajar mahasiswa. Suatu penelitian eksperimen dilakukan untuk melihat pengaruh pembelajaran kalkulus integral dengan menggunakan teknologi komputer program aplikasi Maple. Subyek dari penelitian ini adalah mahasiswa pendidikan matematika semester dua. Dua kelas dipilih dengan menggunakan teknik sampling untuk dijadikan kelas kontrol dan kelas eksperimen. Instrumen yang digunakan untuk mengumpulkan data dalam penelitian ini terdiri dari tes matematika untuk menunjukkan prestasi belajar yang berisi soal-soal kalkulus integral dan angket skala sikap motivasi belajar. Dari hasil analisis data secara statistik pada tingkat signifikansi $\alpha=0,05$, ditemukan bahwa pencapaian prestasi belajar mahasiswa kelas eksperimen yang diberikan perlakuan dengan menggunakan bantuan program aplikasi Maple lebih baik secara signifikan dibandingkan dengan pencapaian siswa kelas kontrol, yaitu kelas yang diajar dengan metode klasikal. Berdasarkan jawaban-jawaban dari angket sikap mahasiswa, ternyata mahasiswa termotivasi dan memberikan sikap positif terhadap pembelajaran dengan menggunakan program aplikasi Maple.
\end{abstract}

Kata kunci : program maple, prestasi, motivasi belajar. 


\section{PENDAHULUAN}

Kalkulus Integral merupakan ilmu dasar yang perlu dikuasai secara lebih luas dan mendalam oleh para mahasiswa karena merupakan dasar bagi penguasaan beberapa mata kuliah lainnya yang tingkatannya lebih tinggi seperti teori peluang, metode numerik, dan kalkulus peubah banyak. Ini mengindikasikan bahwa keberhasilan mahasiswa pada perkuliahan kalkulus Integral akan berpengaruh positif terhadap prestasinya kelak pada perkuliahan lanjutan seperti tersebut diatas. Dengan demikian penguasaan konsep, penalaran, dan pemecahan masalah harus diupayakan sedini mungkin. Namun faktanya, prestasi belajar mahasiswa pada perkuliahan kalkulus integral belum begitu menggembirakan.

Hal ini didukung oleh pendapat Rukmana (1999), mengatakan bahwa penguasaan konsep dalam kalkulus sebagai syarat mengikuti kuliah analisis real ternyata tidak lebih dari 50\%. Demikian juga halnya dengan Juandi (1999) yang mengatakan bahwa angka kelulusan hasil belajar kalkulus tiap tahun selalu kurang dari 20\%. Salah satu alasan yang cukup rasional mungkin selama ini kegiatan pembelajaran kalkulus dapat dikatakan tidak menarik, bahkan membosankan. Karena itu merupakan suatu tantangan dan tuntutan bagi dosen untuk selalu mengembangkan model pembelajaran kalkulus yang diharapkan dapat meningkatkan kemampuan kalkulus para mahasiswanya. Karena itu diperlukan upaya membuat model belajar yang lebih baik, menarik minat, menumbuhkan motivasi, dan menyenangkan. Salah satu pilihan adalah digunakannya software yang memuat ilustrasi berupa demonstrasi dan animasi konsep kalkulus integral seperti bagaimana memahami integral Riemann, limit secara intuitif, konsep turunan sebagai ungkapan limit, dan konsep lainnya yang berkaitan dengan kehidupan nyata.

Data prestasi belajar mahasiswa tiga tahun tetakhir ini rata-rata ada sekitar $6,9 \%$ dari peserta kuliah yang tidak lulus pertahunnya. Begitu pula bila kita kaji banyaknya mahasiswa yang mencapai kelulusan dengan nilai A, B dan C yaitu 16,8 $\%, 18,1 \%$, dan $38,9 \%$, ini mencerminkan bahwa masih banyak mahasiswa belum begitu memahami dan menggunakan daya nalarnya untuk mata kuliah kalkulus integral sedangkan kalkulus integral menjadi prasyarat untuk mata kuliah lainnya. Salah satu alasan yang cukup rasional mungkin selama ini kegiatan belajar mengajar kalkulus dapat dikatakan tidak menarik, bahkan membosankan. Oleh karena itu merupakan suatu tantangan dan tuntutan bagi dosen untuk selalu mengembangkan model pembelajaran kalkulus yang diharapkan dapat meningkatkan kemampuan kalkulus integral para mahasiswanya. Tetapi kenyataan yang dihadapi sampai saat ini terkait dengan pembelajaran kalkulus integral adalah belum ada upaya untuk memanfaatkan teknologi untuk membantu pada proses mentransfer ilmu. Seiring dengan pesatnya perkembangan teknologi, telah berkembang beberapa paket aplikasi matematika seperti Maple, Mathematica, dan MatLab yang memungkinkan mahasiswa mengeksplorasi pembelajaran kalkulus integral dengan lebih luas dan mendalam. Sankey (2005) mengatakan bahawa tren terhadap penggunaan teknologi multimedia pembelajaran sebagai basis pengajaran telah mengalami peningkatan. 
Hal senada juga disampikan oleh Powers (2005) Saat ini perubahan kurikulum yang mengintegrasikan penggunaan teknologi dalam pengajaran sedang dilakukan di berbagai negara. Untuk itu, guru atau dosen dan sebagai pengajar harus menguasai teknologi.

Melihat dari kenyataan di atas, dosen perlu mengupayakan suatu model perkuliahan yang dapat mengaktifkan mahasiswa pada perkuliahan serta merangsang motivasi belajarnya yang pada akhirnya terjadi peningkatan prestasi belajar mahasiswa. Pemanfaatan teknologi komputer berupa suatu program software dalam pembelajaran kalkulus integral sebenarnya sudah merupakan suatu kebijakan yang harus dipersiapkan dan diterapkan. Di samping itu, materi-materi kalkulus integral tidak hanya dapat dipahami melalui proses analisis dan aljabar tetapi juga diperkuat dengan bantuan aplikasi program komputer dalam rangka meningkatkan prestasi mahasiswa pada penguasaan kalkulus integral. Yang lebih penting lagi adalah melalui pemanfaatan suatu software pada komputer nantinya diharapkan mahasiswa lebih termotivasi untuk meningkatkan dan mengembangkan kemampuannya, berlatih Kalkulus secara mandiri dengan mudah, teratur dan tidak membosankan (Candiasa, 2004).

Hasil penelitian terdahulu menyatakan bahwa keuntungan yang dapat diperoleh melalui pemanfaatan komputer sebagai media dalam pembelajaran diantaranya adalah kelebihannya dalam mempresentasikan grafik dan gambar sebagai bentuk visual yang dapat diamati dan dipelajari mahasiswa dalam konseptualisasi dan pemodelan matematika. Candiasa (2004) menyatakan bahwa komunikasi pembelajaran bermedia komputer dapat meningkatkan motivasi belajar dan kemampuan aplikasi komputer mahasiswa. Karim (2003) menyatakan bahwa penggunaan teknologi di kelas, menunjukkan adanya peningkatan kemampuan untuk belajar dan menerapkan metode matematika dalam memecahkan masalah dalam kehidupan nyata dan juga memanfaatkan metode tersebut dalam penalaran dan berpikir kritis untuk membuat suatu keputusan. Misalnya, dalam mengevaluasi dan grafik berbagai jenis fungsi dengan software Maple. Ariawan (2004) menunjukkan bahwa penggunaan program Maple pada perkuliahan kalkulus dapat meningkatkan motivasi dan prestasi belajar.

Dari uraian diatas diduga ada peningkatan prestasi, motivasi belajar dan sikap positif mahasiswa pada pembelajaran kalkulus integral dengan memanfatkan program aplikasi Maple. Oleh karena itu peneliti tertarik untuk mengadakan upaya peningkatan prestasi dan motivasi belajar mahasiswa pada perkuliahan kalkulus integral melalui pemanfaatan program aplikasi Maple.

Permasalahan yang akan diupayakan pemecahannya melalui penelitian ini dapat diuraikan sebagai berikut.

a. Sejauh mana peningkatan motivasi belajar mahasiswa dalam perkuliahan kalkulus diferensial melalui pemanfaatan program Maple?

b. Bagaiman motivasi mahasiswa dalam perkuliahan kalkulus integral melalui pemanfaatan program Maple? 
c. Bagaimana tanggapan mahasiswa terhadap pemanfaatan program Maple pada perkuliahan kalkulus integral?

Tujuan utama dari penelitian ini adalah untuk menemukan format model pembelajaran kalkulus integral yang berbasis komputer (khususnya program Maple) yang dapat mengoptimalkan proses dan hasil pembelajaran kalkulus integral sehingga akan tercapai tujuan akhir yaitu :

a. Meningkatkan prestasi belajar mahasiswa dalam perkuliahan kalkulus integral melalui pemanfaatan program Maple.

b. Memunculkan motivasi belajar mahasiswa dalam perkuliahan kalkulus integral melalui pemanfaatan program aplikasi Maple.

c. mendeskripsikan tanggapan mahasiswa terhadap pemanfaatan program Maple pada perkuliahan kalkulus integral .

Usaha untuk memperbaiki perkuliahan kalkulus integral dalam rangka meningkatkan prestasi dan motivasi mahasiswa dalam memahami dan mendalami kalkulus integral agar sesuai dengan yang diharapkan, peneliti melakukan inovasi pembelajaran dengan menggunakan media berupa teknologi komputer yang tersedia dan cocok diterapkan dalam matakuliah kalkulus, yaitu program aplikasi Maple. Adapun model pembelajaran yang akan diterapkan dalam penelitian ini adalah pembelajaran yang merupakan modifikasi antara pembelajaran klasikal, dan kegiatan praktikum berbasis komputer. Pembelajaran klasikal dilaksanakan pada penyampaian informasi materi kalkulus sesuai dengan silabus jurusan pendidikan matematika. Dalam pembelajaran kelas responsi dilaksanakan sebagai pemantapan akan materi yang telah diajarkan pada pembelajaran klasikal. Sedangkan kegiatan praktikum dilaksanakan untuk mengecek atau membandingkan hasil perghitungan, serta menampilkan visualisasi gambar grafik fungsi dan bentuk daerah dari benda putar dengan menggunakan program Maple.

Berikut ini adalah tampilan dari program Maple dalam menyelesaikan persoalan volume benda putar yang terjadi dari suatu daerah dikuadran I yang dibatasi oleh kurva $y=1-\frac{1}{4} x^{2}$, sumbu $x$ dan sumbu $y$, daerah tersebut diputar mengelilingi sumbu $\mathrm{x}$.

Bentuk selesaikan masalah dengan program Maple sebagai berikut

$$
\begin{aligned}
V & =\pi \int_{0}^{2}\left(1-\frac{1}{4} x^{2}\right)^{2} d x \\
& =\int_{0}^{2} \frac{1}{16} \pi\left(-4+x^{2}\right)^{2} d x \\
& =\frac{16}{15} \pi
\end{aligned}
$$


Ilustrasi daerah benda putarnya adalah sebagai berikut

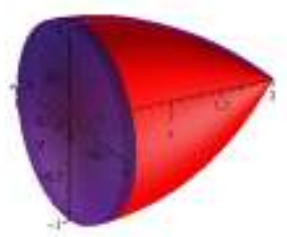

Gambar 1. Daerah Benda Putar

Ilustrasi daerah benda putar ini memberikan gambaran bahwa untuk menghitung volume benda putar adalah dengan cara melakukan partisi-partisi daerah benda putar sebanyak $\mathrm{n}$ unit dengan setiap unitnya akan berbentuk silinder, kemudian silinder-silinder yang berbeda ukuran tingginya itu dijumlahkan sehingga diperoleh volume benda putar yang diharapkan. Dengan adanya penyelesaian yang sederhana akan menuntun mahasiswa menggunakan nalarnya untuk menemukan penyelesaian hasilnya secara lengkap dan dengan adanya gambar daerah benda putar maka mahasiswa dengan daya nalarnya dapat memahami konsep dasar dari menghitung volume benda putar. Selain dari itu mahasiswa dapat berlatih untuk menguasai konsep kalkulus integral dengan bereksperimen untuk membuat soal dan menyelesaikannya dengan bantuan program Maple. Dengan demikian diharapkan mahasiswa dpat meguasaikonsep dengan baik

Di samping pengajaran yang dilakukan secara klasikal (untuk mendapatkan hasil integral suatu fungsi dan hasil kuantitatifnya) maka merepresentasikan fungsi dan integral fungsi yang dimaksud secara visual dalam bentuk grafik dan gambar daerah, akan mempertajam pemahaman dan daya nalar mahasiswa terhadap pengertian integral fungsi.

\section{METODE PENELITIAN}

Penelitian ini menggunakan metode penelitian eksperimen dengan menggunakan desain "kelompok kontrol non-ekivalen" yang merupakan bagian dari bentuk "kuasi eksperimen". Yang dijadikan subjek dalam penelitian ini adalah mahasiswa semester II, Jurusan Pendidikan Matematika UIN SUSKA Riau tahun akademik 2014/2015. Pengambilan sampelnya menggunakan teknik random sampling yaitu pengambilan sampel secara acak berdasarkan kelompok yang telah ada sebelumnya. Pengambilan kelompok eksperimen didasarkan atas kapasitas laptop yang ada pada mahasiswa. Dalam penelitian ini penggunaan aplikasi Maple sebagai salah satu model pembelajaran diberikan pada kelompok eksperimen, sedangkan kelompok kontrol menggunakan pembelajaran biasa (klasikal). 
Materi ajar integral dan seperangkat soal telah dirancang untuk dijadikan sebagai instrumen dalam penelitian ini. Materi ajar integral disajikan secara klasikal dan praktikum berbantuan Maple. Sebanyak 5 soal digunakan sebagai alat untuk memperoleh data prestasi mahasiswa.

Data yang dikumpulkan dalam penelitian ini meliputi hasil tes, motivasi, dan tanggapan mahasiswa terhadap pelaksanaan kegiatan penggunaan software Maple 13 dalam perkuliahan Kalkulus integral. Data yang terkait dengan motivasi dan tanggapan mahasiswa terhadap pemanfaatan aplikasi Maple dijaring melalui angket, dengan skala instrumen dalam penelitian ini adalah skala Likert. Data tes, yaitu sebelum mendapat perlakuan, pengetahuan masing-masing kelompok direkam melalui kegiatan ujian pre-test. Setelah mendapat perlakuan pengajaran dengan memanfaatkan aplikasi Maple untuk kelompok eksperimen, sedangkan kelompok kontrol menggunakan pembelajaran biasa, kemudian setelah proses pembelajaran selesai kembali pengetahuan masing-masing kelompok direkam melalui ujian posttest.

Analisis data statistik dilakukan dengan menggunakan software SPSS 17.0 for windows. Bentuk uji hipotesis yang dilakukan adalah dengan uji hipotesis perbedaan dua rata-rata dua sisi (two-tailed test) dengan hipotesis:

$H_{0}: \mu_{\text {postest-eksperimen }}=\mu_{\text {postest-kontrol }}$

$H_{1}: \mu_{\text {postest-eksperimen }} \neq \mu_{\text {postest-kontrol }}$

$H_{o}$ : Tidak terdapat perbedaan antara rata-rata skor post-tes prestasi mahasiswa kelas eksperimen dengan kelas kontrol.

$H_{1}$ : Terdapat perbedaan antara rata-rata skor post-tes prestasi mahasiswa kelas eksperimen dengan kelas kontrol.

\section{HASIL PENELITIAN DAN PEMBAHASAN}

\section{Hasil Penelitian}

\section{Prestasi Mahasiswa}

Berdasarkan data yang diperoleh dari hasil penelitian untuk kelas eksperimen dan kelas kontrol pada pre-test, maka didapatkan hasil sebagai berikut :

Tabel 1. Deskripsi kemampuan awal mahasiswa

\begin{tabular}{|c|c|c|c|c|c|c|c|c|c|c|c|}
\hline \multirow{2}{*}{ Aspek } & Skore & \multicolumn{4}{|c|}{ pre-test Kelas Eksperimen } & \multicolumn{4}{c|}{ pre-test Kelas Kontrol } \\
\cline { 3 - 12 } & ideal & Min & $\operatorname{Max}$ & $\bar{X}$ & $S$ & $\%$ & Min & Max & $\bar{X}$ & $S$ & $\%$ \\
\hline $\begin{array}{c}\text { Prestasi } \\
\text { mahasiswa }\end{array}$ & 15 & 2 & 7 & 4,8 & 1,65 & 30 & 1 & 7 & 4,16 & 1,66 & 26,04 \\
\hline
\end{tabular}

Tabel 1 menunjukkan sebaran data pada kelas eksperimen dan kelas kontrol relatif sama, rata-rata hasil pre-test prestasi mahasiswa kelas eksperimen dan kontrol tidak ada perbedaan, rata-rata prestasi mahasiswa pada kelas ekperimen dan kontrol memiliki selisih sebesar 0,63 atau 3,96\%.

Setelah mengetahui kemampuan awal dari masing-masing kelas melalui skor pre-test langkah berikutnya adalah memberi perlakuan terhadap masing-masing 
kelas di mana kelas eksperimen mendapatkan perlakuan metode mengajar berbantuan Maple sedangkan kelas kontrol, mendapatkan perlakuan mengajar klasikal. Kemudian dilakukan post-test dengan hasil sebagaimana ditunjukan pada tabel 2.

Tabel 2. Deskripsi Hasil Skor Post-test Prestasi Mahasiswa

\begin{tabular}{|c|c|c|c|c|c|c|c|c|c|c|c|}
\hline \multirow{2}{*}{ Aspek } & \multirow{2}{*}{$\begin{array}{c}\text { Skor } \\
\text { Ideal }\end{array}$} & \multicolumn{4}{|c|}{ post-test Kelas Eksperimen } & \multicolumn{5}{|c|}{ post-test Kelas Kontrol } \\
\cline { 3 - 13 } & Min & $\operatorname{Max}$ & $\bar{X}$ & $\%$ & $S$ & Min & Max & $\bar{X}$ & $\%$ & $S$ \\
\hline $\begin{array}{c}\text { Prestasi } \\
\text { mahasiswa }\end{array}$ & 15 & 4 & 15 & 11,33 & 70,83 & 2,64 & 4 & 12 & 8,13 & 50,83 & 2,16 \\
\hline
\end{tabular}

Berdasarkan Tabel 2 rata-rata skor hasil post-test prestasi mahasiswa pada kelas ekperimen lebih baik daripada kelas kontrol. Selisih rata-rata antara kelas ekperimen dan kelas kontrol adalah 3,20 atau 20\%. Untuk mengetahui signifikan tidaknya perbedaan skor hasil post-test kelas eksperimen dan kelas kontrol, dilakukan uji perbedaan dua rata-rata dengan menggunakan uji-t.

Hasil uji perbedaan dua rata-rata skor postes pada kelas eksperimen dan kelas kontrol dapat dilihat pada Tabel 3 berikut ini.

Tabel 3. Hasil Uji Perbedaan Rata-rata Skor Post-test Prestasi Mahasiswa

\begin{tabular}{|c|c|c|c|c|}
\hline Aspek & $t$ & Sig.(2-tailed) & Kesimpulan & Keterangan \\
\hline Prestasi mahasiswa & 5,133 & 0,000 & Tolak $\mathrm{H}_{0}$ & $\begin{array}{c}\text { Terdapat } \\
\text { Perbedaan }\end{array}$ \\
\hline
\end{tabular}

Tabel 3 memperlihatkan hasil uji perbedaan rata-rata skor post-test pada kedua kelas memiliki $P$-value(2-tailed) sebesar $\frac{0,000}{2}=0,000<\alpha=0,05$, sehingga menolak $\mathrm{H}_{0}$. Berarti terdapat perbedaan yang signifikan terhadap prestasi mahasiswa pada kelas eksperimen dan kontrol. Dari data yang ditunjukan pada tabel 1 dan tabel 2 , terlihat ada peningkatan (gain) yang terjadi. Peningkatan ini selanjutnya ditunjukan oleh indeks $N$-gain pada tabel 4 .

Tabel 4. Gain Ternormalisasi Kelas Eksperimen dan Kontrol

\begin{tabular}{|c|c|c|c|c|}
\hline \multirow{2}{*}{ Aspek } & \multicolumn{2}{|c|}{ Kelas Eksperimen } & \multicolumn{2}{c|}{ Kelelas Kontrol } \\
\cline { 2 - 5 } & $\begin{array}{c}\text { Rata-rata } \\
N \text {-Gain }\end{array}$ & $\begin{array}{c}\text { Kategori } \\
N \text {-Gain }\end{array}$ & $\begin{array}{c}\text { Rata-rata } \\
N \text {-Gain }\end{array}$ & $\begin{array}{c}\text { Kategori } \\
N \text {-Gain }\end{array}$ \\
\hline $\begin{array}{c}\text { Prestasi } \\
\text { Mahasiswa }\end{array}$ & 0,631 & Sedang & 0,421 & Sedang \\
\hline
\end{tabular}

Berdasarkan Tabel 4. rata-rata gain ternormalisasi prestasi mahasiswa pada kelas eksperimen dan kelas kontrol berada pada kategori sedang. Tetapi rata-rata gain ternormalisasi pada kelas eksperimen lebih baik daripada kelas kontrol. Selisih rata-rata $\mathrm{N}$-gain prestasi mahasiswa eksperimen dan kontrol adalah 0,210. 
Untuk menguji perbedaan rata-rata $N$-gain prestasi mahasiswa kelas eksperimen dan kelas kontrol dilakukan dengan melakukan uji perbedaan rata-rata menggunakan SPSS 17.0. for Windows. Dengan kriteria

$H_{o}$ : Peningkatan prestasi yang mendapat pembelajaran dengan penggunaan program aplikasi Maple lebih rendah atau sama dengan siswa yang mendapat pembelajaran klasikal.

$H_{1}$ : Peningkatan kemampuan berpikir kritis matematis siswa yang mendapat pembelajaran berbasis masalah berbantuan program Cabri $3 D$ lebih baik daripada siswa yang mendapat pembelajaran klasikal.

Hasil perhitungan dengan SPSS diperoleh hasil sebagai berikut,

Tabel 5. Hasil Uji Perbedaan Rata-rata Skor Gain Prestasi Mahasiswa

\begin{tabular}{|c|c|c|c|c|}
\hline Aspek & $t$ & Sig.(2-tailed) & Kesimpulan & Keterangan \\
\hline Prestasi Mahasiswa & 4,532 & 0,000 & Tolak $\mathrm{H}_{0}$ & $\begin{array}{c}N \text {-Gain lebih } \\
\text { baik }\end{array}$ \\
\hline
\end{tabular}

Tabel 5 memperlihatkan nilai signifikansi hasil perhitungan uji perbedaan rata-rata (uji- $t$ ) $\quad N$-gain kelas eksperimen dan kelas kontrol memiliki $P$-value (2tailed) sebesar $\frac{0,000}{2}=0,000<\alpha=0,05$. Ini menunjukkan $\mathrm{H}_{0}$ ditolak, artinya peningkatan prestasi mahasiswa yang mendapat pembelajaran dengan penggunaan program aplikasi maple lebih baik daripada siswa yang mendapat pembelajaran klasikal.

\section{Hasil Skala Sikap dan Motivasi Mahasiswa}

Pemberian skala sikap dan motivasi mahasiswa dalam penelitian ini bertujuan untuk mengetahui sikap dan motivasi mahasiwa terhadap pembelajaran dengan menggunakan aplikasi sofware Maple, Sebelum dianalisis, hasil skala sikap dan motivasi mahasiswa ini di transformasi setiap pernyataannya untuk diuji validitas, mengetahui skor sikap siswa dan skor netral.

Sikap mahasiwa terhadap pembelajaran dengan menggunakan aplikasi sofware Maple, ditunjukkan melalui indikator yang menunjukkan kesukaan terhadap terhadap pembelajaran dengan menggunakan apliksi sofware Maple.

Tabel 6. Sikap dan Motivasi Mahasiwa Terhadap Pembelajaran dengan Menggunakan Aplikasi Sofware Maple

\begin{tabular}{|c|c|c|c|c|c|c|c|c|c|c|c|c|c|c|c|}
\hline \multirow{4}{*}{$\begin{array}{l}\text { Sikap } \\
\text { Siswa }\end{array}$} & \multirow{4}{*}{ Indikator } & \multirow{2}{*}{\multicolumn{2}{|c|}{ Pernyataan }} & \multirow{2}{*}{\multicolumn{8}{|c|}{ Jawaban }} & \multicolumn{4}{|c|}{ Skor Sikap } \\
\hline & & & & & & & & & & & & & & & \\
\hline & & \multirow{2}{*}{ No } & \multirow{2}{*}{ Sifat } & \multicolumn{2}{|c|}{ SS } & \multicolumn{2}{|c|}{$\mathrm{S}$} & \multicolumn{2}{|c|}{ TS } & \multicolumn{2}{|c|}{ STS } & Item & Mean & Item & Mean \\
\hline & & & & $\mathrm{n}$ & $\%$ & $\mathrm{n}$ & $\%$ & $\mathrm{n}$ & $\%$ & $\mathrm{n}$ & $\%$ & & & & \\
\hline \multirow{2}{*}{$\begin{array}{l}\text { Sikap siswa } \\
\text { terhadap } \\
\text { pembelajaran } \\
\text { geometri }\end{array}$} & \multirow{2}{*}{$\begin{array}{l}\text { Menunjukkan kesukaan } \\
\text { terhadap materi } \\
\text { pelajaran dengan } \\
\text { menggunakan Maple }\end{array}$} & 1 & $(-)$ & 0 & 0 & 3 & 10 & 18 & 60 & 9 & 30 & 3,00 & \multirow{2}{*}{2,96} & 4,10 & \multirow{2}{*}{3,73} \\
\hline & & 2 & $(+)$ & 12 & 40 & 16 & 53,3 & 2 & 6,67 & 0 & 0 & 3,00 & & 4,27 & \\
\hline
\end{tabular}




\begin{tabular}{|c|c|c|c|c|c|c|c|c|c|c|c|c|c|}
\hline \multirow{4}{*}{$\begin{array}{l}\text { berbantuan } \\
\text { program Cabri } \\
3 D\end{array}$} & \multirow{4}{*}{$\begin{array}{l}\text { Menunjukkan } \\
\text { keseriusan belajar } \\
\text { dengan menggunakan } \\
\text { bantuan Maple }\end{array}$} & 3 & $(+)$ & 7 & 23 & 11 & 36,7 & 11 & 36,7 & 1 & 3,33 & 2,50 & 2,80 \\
\hline & & 4 & $(-)$ & 0 & 0 & 8 & 26,7 & 18 & 60 & 4 & 13,3 & 3,50 & 4,00 \\
\hline & & 5 & $(+)$ & 16 & 53 & 7 & 23,3 & 7 & 23,3 & 0 & 0 & 3,25 & 4,30 \\
\hline & & 6 & $(-)$ & 1 & 3,3 & 7 & 23,3 & 15 & 50 & 7 & 23,3 & 2,50 & 2,93 \\
\hline
\end{tabular}

Dari 6 pernyataan yaitu nomor 1, 2,3,4,5 dan 6 menunjukkan rata-rata skor sikap siswa yaitu 3,73 lebih besar daripada skor netralnya sebesar 2,96. Sehingga dapat disimpulkan bahwa sikap dan motivasi mahasiswa positif terhadap pembelajaran dengan menggunakan aplikasi Maple. Yang berarti bahwa mahasiswa menyukai dan tertarik untuk mengikuti perkuliahan kalkulus integral dangan menggunakan aplikasi software Maple, mahasiswa dengan antusias dan serius mencoba untuk membuat soal baru dan menyelesaikannya, kemudian soal tersebut dibandingkan dengan penyelesaian oleh aplikasi Maple. Dengan adanya aplikasi maple mahasiswa menjadi termotivasi untuk lebih menguasai materi kalkulus integral dengan melalui percobaan-percobaan.

\section{PENUTUP}

\section{Kesimpulan}

Berdasarkan hasil penelitian dan pembahasan mengenai peningkatan prestasi, dan motivasi mahasiwa yang mendapat pembelajaran dengan menggunakan program aplikasi maple dan mahasiswa yang mendapat pembelajaran klasikal, serta sikap siswa terhadap pembelajaran dengan menggunakan program aplikasi maple, maka diperoleh kesimpulan sebagai berikut.

1) Peningkatan prestasi belajar mahasiswa dalam perkuliahan kalkulus diferensial melalui pemanfaatan program maple lebih baik daripada siswa yang mendapat pembelajaran klasikal.

2) Peningkatan motivasi belajar mahasiswa dalam perkuliahan kalkulus diferensial melalui pemanfaatan program aplikasi maple lebih baik daripada siswa yang mendapat pembelajaran konvensional.

Sikap siswa positif terhadap pembelajaran dengan menggunakan program maple pada perkuliahan kalkulus diferensial .

\section{Saran}

Beberapa saran yang dapat diberikan terkait dengan Penelitian ini adalah sebagai berikut.

1) Perlu diadakannya kegiatan praktikum pada perkuliahan di Jurusan Pendidikan Matematika.

2) Penggunaan program Aplikasi Maple dapat diperluas pada perkuliahan lainnya seperti Kalkulus integral, Metode Numerik, Statistik dan lain sebagainya.

Perlu pengembangan bahan ajar diikuti praktikum dengan memanfaatkan teknologi komputasi program aplikasi Maple pada perkuliahan di jurusan pendidikan matematika. 


\section{DAFTAR PUSTAKA}

Ariawan,I.P.W. (2004). Efektivitas Pemanfaatan Program Maple dalam Perkuliahan Kalkulus. Laporan Penelitian. Singaraja : IKIP N Singaraja

Candiasa, I.M. (2004). Komunikasi Pembelajaran Bermedia Komputer. Laporan Penelitian. Singaraja : IKIP N Singaraja

Juandi, D. (1999). Pengoptimalan Penggunaan Media Pembelajaran dalam Peningkatan Hasil Belajar kalkulus di FPMIPA UPI Bandung. Penelitian UPI Bandung: Tidak diterbitkan.

Karim, N.(2003). Use of IT \& Maple in Teaching Pre-calculus. The Mathematics Education into the 21st Century Project. Procedings of the International conference. Brno, Czech Republic, Sepember 2003.

Powers, R and Blubaugh, W. (2005). Technology in Mathematics Education: Preparing Teachers for The Future. Contemporary Issues in Technology and Teacher Education Vol. 5 (3/4),

Rukmana, K. (2000). Suatu Alternatif Model Pembelajaran Perkuliahan Analisis Real I Sebagai Salah satu saha dalam Meningkatkan Kemampuan Berfikir dan Bernalar Secara matematik pada Mahasiswa Jurusan Pendidikan Matematika. Penelitian UPI Bandung: Tidak Diterbitkan

Sankey, M., (2005). Multimodal Design and The Neomillenial Learner. Proceedings of OLT 2005 Conference, Brisbane, Australia, 27 September 2005. 